\title{
RESEARCH
}

Open Access

\section{Effects of free-air $\mathrm{CO}_{2}$ enrichment (FACE) and nitrogen $(\mathrm{N})$ supply on $\mathrm{N}$ uptake and utilization of indica and japonica cultivars (Oryza sativa L.)}

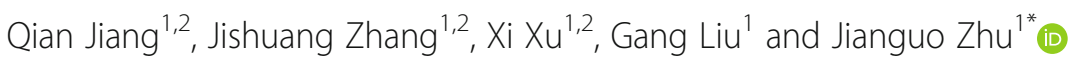

\begin{abstract}
Background: Increasing atmospheric $\left[\mathrm{CO}_{2}\right]$ can increase photosynthesis and promote plant growth, consequently influencing nitrogen $(\mathrm{N})$ cycling. Yet, there is no systematic information on the $\mathrm{N}$ response among different organs of japonica and indica rice genotypes to elevated $\left[\mathrm{CO}_{2}\right]$ as affected by $\mathrm{N}$ application. To investigate the impacts of elevated $\left[\mathrm{CO}_{2}\right]$ and $\mathrm{N}$ fertilization on $\mathrm{N}$ uptake and utilization of different genotypic rice (Oryza sativa L.) during grain filling, a free-air $\mathrm{CO}_{2}$ enrichment (FACE) experiment with indica CV. Liangyou 084 (IIY084) and japonica CV. Wuyunjing 23 (WYJ23) was conducted in Eastern China. Crops were exposed to ambient $\left[\mathrm{CO}_{2}\right]$ and elevated $\left[\mathrm{CO}_{2}\right]$ ( $200 \mathrm{\mu mol} \mathrm{mol}^{-1}$ above ambient) at two levels of $\mathrm{N}$ : control (ON) and $22.5 \mathrm{~g} \mathrm{~N} \mathrm{~m}^{-2}$ (normal N, NN), and they were sampled at 82 days after transplanting (DAT), 99 DAT, and maturity, respectively.

Results: Under FACE, significant declines of $\mathrm{N}$ concentration in all tissues and the whole plants were observed with the greater decrease in leaves and stems at three stages. Positive responses of $\mathrm{N}$ use efficiency (NUE) to elevated $\left[\mathrm{CO}_{2}\right]$ were recorded over the study period. The total $\mathrm{N}$ accumulation remained unchanged, while a large amount of $\mathrm{N}$ was partitioned to panicles at the expense of leaves and stems. As compared to WYJ23, greater $\mathrm{N}$ transportation from roots to aboveground, especially the panicles, was observed on IIY084 accompanied by higher panicle biomass (82 DAT and 99 DAT), N concentrations (maturity), and greater NUE for leaves through the study season. Across all $\left[\mathrm{CO}_{2}\right]$ and cultivars, $\mathrm{N}$ fertilization increased $\mathrm{N}$ partitioning to leaves and stems while decreasing that to panicles. Additionally, $\mathrm{N}$ supply decreased NUE while stimulating $\mathrm{N}$ concentrations and $\mathrm{N}$ amounts of rice plants. Among all treatments, IIY084 had the highest $\mathrm{N}$ accumulation and allocation in panicles under elevated $\left[\mathrm{CO}_{2}\right]$ in combination with $\mathrm{N}$ fertilizer at maturity.
\end{abstract}

Conclusion: Data from this study were helpful for understanding the temporal $\mathrm{N}$ uptake and utilization of different rice genotypes as affected by $\mathrm{N}$ availability and suggest that IIY084 promises a considerable prospect for its grain yield and quality under future elevated atmospheric $\left[\mathrm{CO}_{2}\right]$.

Keywords: Free-air $\mathrm{CO}_{2}$ enrichment (FACE), N use efficiency, N allocation, N concentration, Rice genotypes

\footnotetext{
* Correspondence: jgzhu@issas.ac.cn

'State Key Laboratory of Soil and Sustainable Agriculture, Institute of Soil Science, Chinese Academy of Sciences, No. 71 East Beijing Road, Nanjing 210008, China

Full list of author information is available at the end of the article
}

\section{Springer Open}

(c) The Author(s). 2020 Open Access This article is licensed under a Creative Commons Attribution 4.0 International License, which permits use, sharing, adaptation, distribution and reproduction in any medium or format, as long as you give appropriate credit to the original author(s) and the source, provide a link to the Creative Commons licence, and indicate if changes were made. The images or other third party material in this article are included in the article's Creative Commons licence, unless indicated otherwise in a credit line to the material. If material is not included in the article's Creative Commons licence and your intended use is not permitted by statutory regulation or exceeds the permitted use, you will need to obtain permission directly from the copyright holder. To view a copy of this licence, visit http://creativecommons.org/licenses/by/4.0/. 


\section{Introduction}

Due to the activities of human beings, such as the increasing demands for cultivated lands and energies, global atmospheric $\left[\mathrm{CO}_{2}\right]$ is increasing from $280 \mu \mathrm{mol}$ $\mathrm{mol}^{-1}$ before industrial revolution to $402 \mu \mathrm{mol} \mathrm{mol}^{-1}$ in recent years. By the end of this century, $700 \mu \mathrm{mol} \mathrm{mol}^{-1}$ or more is predicted for atmospheric $\left[\mathrm{CO}_{2}\right]$ (Metz et al. 2007). In general, the projected increase in $\left[\mathrm{CO}_{2}\right]$ is able to directly promote plant growth through raising photosynthesis, especially in C3 plants (Kim et al. 2001, 2003; Tausz et al. 2013). Subsequently, nutrient cycling and utilization, residue decomposition, and even insect-plant interaction might be affected to different extents (Coviella and Trumble 1999; Leakey et al. 2009; Viswanath et al. 2010; Zhu et al. 2016).

Nitrogen $(\mathrm{N})$, accounting for $1-3 \%$ of the whole plant, is one of the essential elements required for plant growth and yield as well as quality and may play a critical role in the responses of plants to elevated $\left[\mathrm{CO}_{2}\right]$ (Kim et al. 2003). Based on both area and tonnage harvested, rice (Oryza sativa L.) is one of the most important crops in the world and the first food in Asia, providing dietary needs to a large population. Considering its vital socio-economic impacts, the variation of $\mathrm{N}$ uptake and utilization of rice in the future has become a focus (Liang et al. 2013; Myers et al. 2014; Roberts et al. 2011; Wei et al. 2011). Overall, previous studies have reported that under elevated $\left[\mathrm{CO}_{2}\right]$, whole plant $\mathrm{N}$ uptake increased, but the concentration on a per unit weight of tissue basis declined with the ranges depending on factors such as experimental facility, $\mathrm{N}$ supply, cultivar, and growth stage (Terao et al. 2005; Yang et al. 2007a, 2007b; Zhu et al. 2018).

Studies with different rice cultivars have presented clear genotype-dependent effects of elevated $\left[\mathrm{CO}_{2}\right]$ on yield and grain quality in chambers, greenhouses, and free-air $\mathrm{CO}_{2}$ enrichment (FACE) (Baker 2004; Lv et al. 2020; Zhang et al. 2015; Zhu et al. 2018; Ziska et al. 1996a). Using japonica cv. Wuxiangjin 14 as testing material, Yang et al. (2007a) reported that shoot N concentration under elevated $\left[\mathrm{CO}_{2}\right]$ declined, but $\mathrm{N}$ uptake and use efficiency (NUE) increased by different magnitudes. Also, shoot $\mathrm{N}$ uptake of indica cv. Liangyoupeijiu was revealed to be increased by elevated $\left[\mathrm{CO}_{2}\right]$ (Yang et al. 2009). However, cultivation techniques (such as $\mathrm{N}$ application strategy and irrigation management) and environmental conditions (such as rainfall and temperature) are quite different among the experimental sites and years, especially under field conditions (Yang et al. 2007b). Moreover, the effect of increasing $\left[\mathrm{CO}_{2}\right]$ inside chambers and enclosures can be markedly different from those field experiment which could provide undisturbed field conditions and more reliable measurements (McLeod and Long 1999). Thus, an experiment with different genotypes such as japonica and indica cultivars at FACE is needed. Previous studies have found that most of the crop responses to elevated $\left[\mathrm{CO}_{2}\right]$ were directly or indirectly associated with $\mathrm{N}$ fertilization (Kim et al. 2003; Kimball 2016; Yang et al. 2007a). For example, positive response of photosynthesis to increasing $\left[\mathrm{CO}_{2}\right]$ was highly dependent on the $\mathrm{N}$ levels, increasing proportionally as $\mathrm{N}$ availability increased (Ziska et al. 1996b). In addition, $N$ uptake and utilization of rice plants could vary between growth stages (Yang et al. 2007a). As Kim et al. (2003) reported, FACE decreased $\mathrm{N}$ concentration in leaves across the season, while it increased total $\mathrm{N}$ uptake at panicle initiation but not at maturity. Seed filling stage is crucial to the formation of yield and quality in many crops, and obviously, $\mathrm{N}$ is the determinant (Gregersen et al. 2008). Yet, little detailed information was given on the temporal $\mathrm{N}$ uptake and utilization over the grain filling duration. Also, there is no systematic information on the $\mathrm{N}$ response among different organs of japonica and indica genotypes to FACE as affected by $\mathrm{N}$ application.

Indica cv. Liangyou 084 (IIY084) and japonica cv. Wuyunjing 23 (WYJ23) were extensively planted in East and Southeast China (Zhu et al. 2018), and previous studies have represented that their grain yield increased by different magnitudes at elevated $\left[\mathrm{CO}_{2}\right]$ (Chen et al. 2015; Li et al. 2017). Here, we hypothesized the response of $\mathrm{N}$ traits to elevated $\left[\mathrm{CO}_{2}\right]$ also differs between these two cultivars. In this work, $\mathrm{N}$ concentration, amount, allocation, and NUE in tissues were measured during grain filling using the Chinese Rice FACE platform. Our objectives are (1) to compare whether there are differences in these $\mathrm{N}$ parameters in response to $\mathrm{CO}_{2}$ enrichment between IIY084 and WYJ23 under fully open-area field condition and (2) to determine whether the effects of FACE on $\mathrm{N}$ traits change with crop development. The results obtained here should provide critical implications to select desirable cultivars which present optimal responses of both grain yield and quality at the future $\left[\mathrm{CO}_{2}\right]$.

\section{Materials and methods}

\section{Free-air $\mathrm{CO}_{2}$ enrichment (FACE) site}

The FACE experimental system was located at the Zhongcun village $\left(119^{\circ} 42^{\prime} 0^{\prime \prime} \mathrm{E}, 32^{\circ} 35^{\prime} 5^{\prime \prime} \mathrm{N}\right)$, Yangzhou City, Jiangsu Province, where is a typical agricultural region for rice-wheat rotation system in China. The soil is classified as Shajiang Aquic Cambiosol according to Chinese Soil Taxonomy with a sandy loam texture, and the soil properties were $1.16 \mathrm{~g} \mathrm{~cm}^{-3}$ bulk density, $54 \%$ total porosity, $18.4 \mathrm{~g} \mathrm{~kg}^{-1}$ organic $\mathrm{C}, 1.45 \mathrm{~g}$ $\mathrm{kg}^{-1}$ total $\mathrm{N}$, and $0.63 \mathrm{~g} \mathrm{~kg}^{-1}$ total $\mathrm{P}$ (as $\mathrm{P}_{2} \mathrm{O}_{5}$ ) (Zhu et al. 2016). This area has a typical north subtropical monsoon climate, with mean annual temperature $14.9{ }^{\circ} \mathrm{C}$, mean 
annual rainfall $978.7 \mathrm{~mm}$, a total annual sunshine time of $2132 \mathrm{~h}$, and more than 220 frost-free days.

\section{FACE system}

A detailed description of the FACE system can be found in a previous report (Liu et al. 2002). Briefly, three rectangular paddy fields with similar soils and agronomic histories were used. In total, there were three FACE plots and three ambient controls, and the useful area of each plot was $120 \mathrm{~m}^{2}$ in this FACE system. The centers of the plots were separated from $90 \mathrm{~m}$ to avoid movement of additional $\left[\mathrm{CO}_{2}\right]$ to the ambient plots. Each FACE plot was encircled with an octagonal ring with the diameter of $14 \mathrm{~m}$. It consisted of eight emission tubes which could rise as the plant grew to maintain the $\left[\mathrm{CO}_{2}\right]$ at the top of the canopy. In the ambient plots, plants were grown under ambient $\left[\mathrm{CO}_{2}\right]$ without ring structures. The $\left[\mathrm{CO}_{2}\right]$ in FACE plots was enhanced with $200 \mu \mathrm{mol} \mathrm{mol}^{-1}$ above that of ambient control plots. The targeted $\left[\mathrm{CO}_{2}\right]$ within the FACE plots was automatically controlled using a computer system.

During the experiment in 2014, average daytime $\left[\mathrm{CO}_{2}\right]$ at canopy height was $378 \mu \mathrm{mol} \mathrm{mol}^{-1}$ for the ambient plots and $571 \mu \mathrm{mol} \mathrm{mol}^{-1}$ for FACE plots, respectively. The average temperature was $22.1 \pm 2.4{ }^{\circ} \mathrm{C}$ over the growing season.

\section{Crop cultivation}

Two rice cultivars (Oryza sativa L.), i.e., an indica cv. Liangyou 084 (hereafter called IIY084) and a japonica cv. Wuyunjing 23 (hereafter called WYJ23), were tested in this investigation. Seedlings of two cultivars were raised in seed trays under respective treatments on May 20, 2014. Then, two seedlings per hill were transplanted manually into their corresponding subplots at a spacing of $25 \mathrm{~cm}$ by $16.7 \mathrm{~cm}$ (i.e., 24 hills $\mathrm{m}^{-2}$ ) on June 20 , 2014. The tested treatments were conducted in each FACE and ambient plots as subplots of $6 \mathrm{~m}^{2}$ each.

In this study, two $\mathrm{N}$ levels were conducted: control $(0 \mathrm{~N})$ and $22.5 \mathrm{~g}$ total $\mathrm{N} \mathrm{m}^{-2}$ (normal $\mathrm{N}, \mathrm{NN}$ ) which is recommended to local farmers and was supplied as urea $(\mathrm{N}, 46 \%)$ and a compound fertilizer $\left(\mathrm{N}: \mathrm{P}_{2} \mathrm{O}_{5}: \mathrm{K}_{2} \mathrm{O}=15\right.$ : 15:15). Both $\mathrm{P}$ and $\mathrm{K}$ fertilizers were adopted as compound fertilizer at equal rates of $9 \mathrm{~g}_{2} \mathrm{O}_{5} \mathrm{~m}^{-2}$ and $9 \mathrm{~g}$ $\mathrm{K}_{2} \mathrm{O} \mathrm{m}^{-2}$, and they were applied as basal fertilizer. Separately, $40 \%$ of urea was used before transplanting as basal nutrition, and then $30 \%$ each was applied at tillering and heading stages (Supplementary Table S1). To minimize the mixing of paddy water, $0 \mathrm{~N}$ and $\mathrm{NN}$ treatments were separated from the rest of the subplots with a $30-\mathrm{cm}$ PVC barrier pushed $10 \mathrm{~cm}$ into the soil. The crops in both FACE and ambient plots were surrounded by border plants treated the same way as the experimental plants inside. During the study, standard cultivation practices such as irrigation, midseason drainage, weeding, and insecticide application common to the local region were followed, as described in detail by Shi et al. (2009). All the plants were harvested on October 17, 2014, except for WYJ23 at NN treatments which were reaped 9 days later.

\section{Sampling and measurements}

Across the season, plants were destructively sampled at different times. In order to coincide as close as possible to the flowering, dough, and grain maturity stages of two varieties, sampling dates were fixed at 82, 99 days after transplanting (DAT), and grain maturity. In each subplot, stem numbers of 20 hills were counted randomly so as to ensure representativeness of sampling. After that, two hills with average stem number were sampled at each stage. For each sample, a block of soil $25 \mathrm{~cm}$ wide, $16.7 \mathrm{~cm}$ long, and $15 \mathrm{~cm}$ deep around the individual hill was dug up. The plants were first rinsed carefully with tap water and then rinsed with deionized water. Then, they were separated into root, stem (including leaf sheath), leaf (including living and dead leaf), and panicle. After harvest, the grains were threshed carefully and then dehulled to produce brown rice using a chaffremove machine (JLG-II, China). Tissues as well as brown rice (only at maturity) were oven-dried at $80{ }^{\circ} \mathrm{C}$ until constant weight to derive their dry weights, and then, they were ground to $<0.25 \mathrm{~mm}$ in a stainless mill (FW-100, China), respectively to further analyses.

$\mathrm{N}$ concentration was determined by high temperature combustion (VarioMAX CNS, Elementar, Germany). The accuracy of the analyses was estimated by comparison with a certified reference material GBW07603 from Institute of Geophysical \& Geochemical Exploration, Chinese Academy of Geosciences, and blanks were introduced regularly. $\mathrm{N}$ amount was calculated from measurements of plant biomass multiplied by $\mathrm{N}$ concentration. $\mathrm{N}$ partitioning of each tissue was calculated from the total $\mathrm{N}$ accumulation. $\mathrm{N}$ use efficiencies (NUE) of panicles, leaves, stems, roots, and whole plants were determined as amount of dry matter per unit absorbed $\mathrm{N}\left(\mathrm{g} \mathrm{DM} \mathrm{g}^{-1} \mathrm{~N}\right)$.

\section{Statistical analysis}

Datasets were based on the mean values of each treatment and were analyzed with the statistical package SPSS 19.0 for Windows (SPSS Inc., Chicago, IL, USA) and EXCEL 2010 for Win. A three-way ANOVA was applied to test the effects of $\left[\mathrm{CO}_{2}\right]$, cultivar, and $\mathrm{N}$ fertilizer and their interactions on $\mathrm{N}$ concentration, uptake, use efficiency, and allocation of rice plants with $\left[\mathrm{CO}_{2}\right]$, cultivar and $\mathrm{N}$ as main factors, and ring identity as random factor. A significant level of $P<0.1$ (LSD, $n=3$ ) was used. Standard error was calculated where appropriate. When interactions were significant, a one-way ANOVA 
was used to compare the differences among different treatments. Differences at $P<0.05$ levels (LSD) were considered statistically significant.

\section{Results}

\section{Biomass of four tissues and whole plants}

Across two cultivars and N levels, FACE significantly increased panicle biomass by $24.8 \%$ at 99 DAT $(P<0.05)$ and raised stem biomass by $12.7 \%$ and $17.3 \%$ at 82 DAT $(P<0.1)$ and 99 DAT $(P<0.1)$, respectively. Over the sampling season, biomass of roots was consistently higher at the elevated $\left[\mathrm{CO}_{2}\right]$ across all cultivars and $\mathrm{N}$ levels with average increase of $27.7,19.4$, and $18.1 \%$ at $82 \operatorname{DAT}(P<0.01), 99$ DAT $(P<0.05)$, and maturity $(P<0.1)$, respectively (Tables 1 and 2$)$.

Significant cultivar effects on panicle biomass at 82 DAT $(P<0.01)$ and 99 DAT $(P<0.05)$ and on root biomass at $99 \mathrm{DAT}(P<0.05)$ and maturity $(P<0.01)$ were observed, separately. As expected, $\mathrm{N}$ application substantially increased the biomass of all four tissues or whole plants at most sampling stages. Take the maturity for example, the average biomass of panicles, leaves, stems, roots, and whole plants across all $\left[\mathrm{CO}_{2}\right]$ levels and cultivars increased by $14.4 \%, 104.8 \%, 26.1 \%, 10.7 \%$, and $25.5 \%$, separately (Tables 1 and 2).

During grain filling, significant cultivar $\times \mathrm{N}$ interactions were observed for root biomass $(P<0.01)$ at 99 DAT and leaf and stem biomass $(P<0.1)$ at maturity, respectively. In fertilized treatments, WJY23 had much greater root biomass than IIY084 under both $\left[\mathrm{CO}_{2}\right]$ levels at 99 DAT. At maturity, IIY084 under FACE condition had the lowest leaf and stem biomass in all $0 \mathrm{~N}$ treatments, while an opposite trend was found on stem biomass in NN treatments (Tables 1 and 2).

\section{$\mathrm{N}$ concentrations in four tissues and whole plants}

Through the sampling stages, the overall patterns of changes in $\mathrm{N}$ concentrations in each tissue were generally similar across all treatments (Fig. 1). Averaged

Table 1 Biomass of four tissues and whole plants of two cultivars (IIY084 and WYJ23) subjected to ambient (A) and elevated [CO 2 ] (F) at none $(\mathrm{ON})$ and normal $\mathrm{N}$ levels (NN) at three stages

\begin{tabular}{|c|c|c|c|c|c|c|c|c|}
\hline \multirow{2}{*}{$\begin{array}{l}\text { Growth } \\
\text { stage }\end{array}$} & \multirow{2}{*}{$\begin{array}{l}\mathrm{N} \\
\text { level }\end{array}$} & \multirow[t]{2}{*}{ Cultivar } & \multirow[t]{2}{*}{$\mathrm{CO}_{2}$} & \multicolumn{5}{|c|}{ Biomass (g hill ${ }^{-1}$ ) } \\
\hline & & & & Panicle & Leaf & Stem & Root & Whole plant \\
\hline \multirow[t]{8}{*}{82 DAT } & \multirow[t]{4}{*}{ ON } & \multirow[t]{2}{*}{ IIY084 } & $A$ & $10.7 \pm 1.8 \mathrm{ab}$ & $7.1 \pm 0.7$ & $18.6 \pm 1.5 c$ & $3.5 \pm 0.5 b$ & $39.9 \pm 4.3$ \\
\hline & & & $\mathrm{F}$ & $8.5 \pm 0.7 b c$ & $8.7 \pm 1.0$ & $25.3 \pm 3.0 \mathrm{ab}$ & $3.7 \pm 0.1 b$ & $46.3 \pm 4.7$ \\
\hline & & \multirow[t]{2}{*}{ WYJ23 } & A & $5.1 \pm 1.2 \mathrm{~d}$ & $9.0 \pm 0.6$ & $20.7 \pm 0.9 a b c$ & $3.4 \pm 0.5 b$ & $38.3 \pm 2.6$ \\
\hline & & & $\mathrm{F}$ & $7.4 \pm 0.1 \mathrm{bcd}$ & $7.7 \pm 0.7$ & $19.5 \pm 1.8 b c$ & $4.0 \pm 0.7 b$ & $38.6 \pm 2.8$ \\
\hline & \multirow[t]{4}{*}{ NN } & \multirow[t]{2}{*}{ IIY084 } & A & $12.7 \pm 1.5 \mathrm{a}$ & $15.2 \pm 0.9$ & $25.1 \pm 0.5 \mathrm{abc}$ & $3.8 \pm 0.2 b$ & $56.7 \pm 2.7$ \\
\hline & & & $\mathrm{F}$ & $12.3 \pm 0.3 a$ & $15.5 \pm 3.2$ & $26.3 \pm 0.4 a$ & $5.4 \pm 0.6 \mathrm{a}$ & $59.6 \pm 3.0$ \\
\hline & & \multirow[t]{2}{*}{ WYJ23 } & A & $6.3 \pm 0.7 \mathrm{~cd}$ & $13.5 \pm 1.7$ & $22.1 \pm 3.0 \mathrm{abc}$ & $4.1 \pm 0.5 b$ & $46.0 \pm 5.1$ \\
\hline & & & $\mathrm{F}$ & $8.8 \pm 0.9 b c$ & $14.9 \pm 1.6$ & $27.1 \pm 2.5 \mathrm{a}$ & $5.8 \pm 0.2 \mathrm{a}$ & $56.6 \pm 5.1$ \\
\hline \multirow[t]{8}{*}{99 DAT } & \multirow[t]{4}{*}{ ON } & \multirow[t]{2}{*}{ IIY084 } & A & $31.5 \pm 3.5 \mathrm{ab}$ & $7.9 \pm 1.2$ & $16.2 \pm 2.0$ & $4.8 \pm 0.4 b c$ & $60.1 \pm 6.5 \mathrm{ab}$ \\
\hline & & & $\mathrm{F}$ & $28.9 \pm 5.2 \mathrm{abc}$ & $6.7 \pm 1.4$ & $19.5 \pm 1.8$ & $6.0 \pm 0.3 a b$ & $61.8 \pm 7.3 \mathrm{ab}$ \\
\hline & & \multirow[t]{2}{*}{ WYJ23 } & A & $19.6 \pm 4.4 \mathrm{~cd}$ & $7.6 \pm 0.9$ & $16.9 \pm 2.1$ & $4.6 \pm 0.5 b c$ & $49.0 \pm 8.1 b$ \\
\hline & & & $\mathrm{F}$ & $23.7 \pm 3.7 \mathrm{bcd}$ & $7.4 \pm 0.6$ & $16.6 \pm 4.2$ & $4.9 \pm 1.0 b c$ & $51.8 \pm 10.3 b$ \\
\hline & \multirow[t]{4}{*}{ NN } & \multirow[t]{2}{*}{ IIY084 } & A & $29.1 \pm 0.1 \mathrm{abc}$ & $13.0 \pm 1.4$ & $18.7 \pm 1.0$ & $3.85 \pm 0.1 c$ & $64.6 \pm 2.5 \mathrm{ab}$ \\
\hline & & & $\mathrm{F}$ & $37.2 \pm 2.8 \mathrm{a}$ & $13.9 \pm 0.5$ & $26.1 \pm 2.7$ & $5.04 \pm 0.3 b c$ & $82.3 \pm 5.7 a$ \\
\hline & & \multirow[t]{2}{*}{ WYJ23 } & A & $16.4 \pm 2.6 \mathrm{~d}$ & $14.2 \pm 1.3$ & $23.3 \pm 2.0$ & $6.07 \pm 0.6 \mathrm{ab}$ & $60.0 \pm 5.0 \mathrm{ab}$ \\
\hline & & & $\mathrm{F}$ & $30.8 \pm 3.6 a b c$ & $14.7 \pm 1.8$ & $25.9 \pm 2.1$ & $7.12 \pm 0.5 a$ & $78.5 \pm 8.0 \mathrm{a}$ \\
\hline \multirow[t]{8}{*}{ Maturity } & \multirow[t]{4}{*}{ ON } & \multirow[t]{2}{*}{ IIY084 } & A & $41.7 \pm 4.2$ & $6.1 \pm 0.4 b c$ & $18.0 \pm 1.4 b c$ & $3.1 \pm 0.2$ & $68.9 \pm 6.2$ \\
\hline & & & $\mathrm{F}$ & $34.9 \pm 4.1$ & $4.4 \pm 0.5 c$ & $15.8 \pm 1.7 c$ & $3.2 \pm 0.5$ & $58.3 \pm 6.0$ \\
\hline & & \multirow[t]{2}{*}{ WYJ23 } & A & $32.7 \pm 2.0$ & $6.6 \pm 0.8 b$ & $17.3 \pm 2.1 b c$ & $3.9 \pm 0.4$ & $60.5 \pm 5.1$ \\
\hline & & & $\mathrm{F}$ & $37.5 \pm 6.7$ & $5.9 \pm 1.0 \mathrm{bc}$ & $18.2 \pm 2.6 b c$ & $4.7 \pm 0.8$ & $66.4 \pm 11.0$ \\
\hline & \multirow[t]{4}{*}{ NN } & \multirow[t]{2}{*}{ IIY084 } & A & $38.7 \pm 1.3$ & $11.7 \pm 0.4 \mathrm{a}$ & $21.7 \pm 1.1 \mathrm{ab}$ & $3.3 \pm 0.5$ & $75.3 \pm 7.2$ \\
\hline & & & $\mathrm{F}$ & $48.4 \pm 2.4$ & $12.6 \pm 0.5 a$ & $25.5 \pm 0.6 a$ & $4.2 \pm 0.3$ & $90.7 \pm 3.0$ \\
\hline & & \multirow[t]{2}{*}{ WYJ23 } & A & $37.8 \pm 3.1$ & $11.3 \pm 0.9 a$ & $20.0 \pm 1.1 b c$ & $4.1 \pm 0.4$ & $73.2 \pm 5.2$ \\
\hline & & & $\mathrm{F}$ & $43.0 \pm 1.5$ & $11.5 \pm 0.3 a$ & $20.2 \pm 0.9 b c$ & $4.9 \pm 0.3$ & $79.7 \pm 2.2$ \\
\hline
\end{tabular}


Table $2 \mathrm{~F}$-value and the results of three-way ANOVA (type III) testing the elevated $\left[\mathrm{CO}_{2}\right]$, cultivar, $\mathrm{N}$ fertilizer, and their interactions on biomass, N concentration, and NUE of rice crops at three growth stages

\begin{tabular}{|c|c|c|c|c|c|c|c|c|c|c|c|c|c|c|c|c|}
\hline \multirow{2}{*}{$\begin{array}{l}\text { Growth } \\
\text { stage }\end{array}$} & \multirow[t]{2}{*}{ Treatments } & \multicolumn{5}{|l|}{ Biomass } & \multicolumn{5}{|c|}{$\mathrm{N}$ concentrations } & \multicolumn{5}{|l|}{ NUE } \\
\hline & & Panicle & Leaf & Stem & Root & $\begin{array}{l}\text { Whole } \\
\text { plant }\end{array}$ & Panicle & Leaf & Stem & Root & $\begin{array}{l}\text { Whole } \\
\text { plant }\end{array}$ & Panicle & Leaf & Stem & Root & $\begin{array}{l}\text { Whole } \\
\text { plant }\end{array}$ \\
\hline \multirow[t]{7}{*}{82 DAT } & $\mathrm{CO}_{2}$ & 0.6 & 0.2 & $3.8^{+}$ & $10.7^{* *}$ & 2.1 & 1.4 & $8.6^{* *}$ & $4.8^{*}$ & 0.0 & $3.8^{+}$ & 0.8 & $9.1^{* *}$ & 2.1 & 0.1 & $8.2^{* *}$ \\
\hline & Cultivar & $30.7^{* *}$ & 0.1 & 0.8 & 0.5 & $3.0^{+}$ & 0.9 & $19.0^{* *}$ & 0.0 & 0.5 & 0.0 & 0.9 & $25.4^{* *}$ & 1.9 & 0.4 & $4.6^{*}$ \\
\hline & $\mathrm{N}$ & $8.0^{* *}$ & $38.1^{* *}$ & $7.7^{* *}$ & $12.0^{* *}$ & $22.9^{* *}$ & $12.1^{* *}$ & $195.2^{* *}$ & $88.4^{* *}$ & $20.9^{* *}$ & $138.0^{* *}$ & $11.9^{* *}$ & $218.6^{* *}$ & $64.4^{* *}$ & $13.1^{* *}$ & $173.2^{* *}$ \\
\hline & $\begin{array}{l}\mathrm{CO}_{2} \times \\
\text { cultivar }\end{array}$ & $6.1^{*}$ & 0.2 & 0.4 & 0.1 & 0.3 & 0.3 & 0.0 & 0.5 & $6.5^{*}$ & $5.5^{*}$ & 0.4 & 0.3 & 0.0 & $5.2^{*}$ & 0.1 \\
\hline & $\mathrm{CO}_{2} \times \mathrm{N}$ & 0.5 & 0.1 & 0.0 & $4.1^{+}$ & 0.1 & 0.4 & 0.2 & 0.2 & 1.1 & 0.5 & 0.4 & 0.2 & 0.2 & 1.3 & 0.6 \\
\hline & Cultivar $\times N$ & 1.1 & 0.5 & 0.2 & 0.1 & 0.0 & 0.0 & 0.2 & $4.1^{+}$ & 0.3 & 0.1 & 0.0 & $3.5^{+}$ & $4.3^{*}$ & 0.7 & 2.7 \\
\hline & $\begin{array}{l}\mathrm{CO}_{2} \times \\
\text { cultivar } \times \mathrm{N}\end{array}$ & 0.3 & 0.9 & $4.8^{*}$ & 0.1 & 2.8 & 2.7 & $4.0^{+}$ & 1.8 & 0.2 & 0.1 & 2.7 & $4.1^{+}$ & 0.8 & 0.1 & 1.4 \\
\hline \multirow[t]{7}{*}{99 DAT } & $\mathrm{CO}_{2}$ & $5.9^{*}$ & 0.0 & $3.6^{+}$ & $6.8^{*}$ & $5.7^{*}$ & $9.5^{* *}$ & $19.5^{* *}$ & $7.5^{*}$ & $5.2^{*}$ & $5.5^{*}$ & $15.3^{* *}$ & $39.4^{* *}$ & $19.8^{* *}$ & $5.4^{*}$ & $22.0^{* *}$ \\
\hline & Cultivar & $13.3^{* *}$ & 0.5 & 0.1 & $4.5^{*}$ & 2.8 & 0.0 & 1.5 & 0.0 & 1.5 & 0.72 & 1.8 & $50.8^{* *}$ & 0.2 & 1.5 & 0.0 \\
\hline & N & 1.0 & $58.3^{* *}$ & $13.2^{* *}$ & 1.6 & $13.5^{* *}$ & $100.0^{* *}$ & $229.5^{* *}$ & $59.6^{* *}$ & $32.5^{* *}$ & $51.5^{* *}$ & $141.9^{* *}$ & $510.5^{* *}$ & $176.7^{* *}$ & $36.2^{* *}$ & $208.2^{* *}$ \\
\hline & $\begin{array}{l}\mathrm{CO}_{2} \times \\
\text { cultivar }\end{array}$ & 1.7 & 0.0 & 1.6 & 0.4 & 0.1 & 0.1 & 0.0 & 0.2 & 0.7 & 0.0 & 0.3 & 0.4 & 0.2 & 0.9 & 1.1 \\
\hline & $\mathrm{CO}_{2} \times \mathrm{N}$ & $4.5^{*}$ & 0.7 & 1.1 & 0.3 & $3.4^{+}$ & 0.1 & 1.3 & 1.4 & 0.7 & 0.4 & 2.1 & 5.0 & 2.5 & 0.1 & 0.6 \\
\hline & Cultivar $\times N$ & 0.0 & 0.2 & 1.0 & $15.2^{* *}$ & 0.5 & $9.5^{* *}$ & $31.3^{* *}$ & 0.0 & 0.9 & 1.3 & $14.2^{* *}$ & $113.3^{* *}$ & 0.0 & 0.7 & 0.4 \\
\hline & $\begin{array}{l}\mathrm{CO}_{2} \times \\
\text { cultivar } \times \mathrm{N}\end{array}$ & 0.0 & 0.2 & 0.0 & 0.2 & 0.0 & 0.0 & 0.8 & 0.2 & 0.1 & 0.6 & 0.6 & 0.0 & 0.0 & 0.5 & 1.4 \\
\hline \multirow[t]{7}{*}{ Maturity } & $\mathrm{CO}_{2}$ & 1.6 & 0.4 & 0.4 & $4.2^{+}$ & 1.1 & $18.3^{* *}$ & $10.9^{* *}$ & $11.9^{* *}$ & $9.6^{* *}$ & $16.3^{* *}$ & $23.4^{* *}$ & $13.9^{* *}$ & $21.7^{* *}$ & $7.9^{* *}$ & $27.5^{* *}$ \\
\hline & Cultivar & 1.6 & 0.1 & 1.3 & $9.7^{*}$ & 0.7 & $9.0^{* *}$ & $3.7^{+}$ & 1.4 & 0.1 & 1.9 & $3.6^{+}$ & $10.1^{* *}$ & 0.9 & 0.4 & 0.6 \\
\hline & $N$ & $4.4^{*}$ & $169.9^{* *}$ & $16.4^{* *}$ & 1.6 & $16.0^{* *}$ & $109.2^{* *}$ & $67.3^{* *}$ & $42.9^{* *}$ & $59.7^{* *}$ & $77.6^{* *}$ & $133.6^{* *}$ & $116.9^{* *}$ & $171.3^{* *}$ & $83.7^{* *}$ & $161.1^{* *}$ \\
\hline & $\begin{array}{l}\mathrm{CO}_{2} \times \\
\text { cultivar }\end{array}$ & 0.5 & 0.1 & 0.0 & 0.2 & 0.2 & 2.7 & 0.2 & 1.2 & 0.0 & 1.3 & 1.4 & 0.2 & 0.0 & 0.4 & 0.4 \\
\hline & $\mathrm{CO}_{2} \times \mathrm{N}$ & 2.8 & $3.7^{+}$ & 1.4 & 0.5 & 2.7 & 0.1 & 2.5 & $7.9^{* *}$ & $6.5^{*}$ & 2.5 & $3.6^{+}$ & 0.1 & $3.2^{+}$ & 2.7 & 0.0 \\
\hline & Cultivar $\times N$ & 0.0 & $3.5^{+}$ & $3.8^{+}$ & 0.4 & 0.6 & $30.1^{* *}$ & 0.2 & 1.4 & 0.1 & $5.3^{*}$ & $28.7^{* *}$ & $4.1^{+}$ & 0.5 & 0.5 & $6.4^{*}$ \\
\hline & $\begin{array}{l}\mathrm{CO}_{2} \times \\
\text { cultivar } \times \mathrm{N}\end{array}$ & 2.6 & 0.9 & 2.3 & 0.3 & 2.4 & $4.5^{*}$ & 0.2 & 2.1 & 1.9 & 2.3 & 1.9 & 0.4 & 2.5 & 2.8 & 1.6 \\
\hline
\end{tabular}

${ }^{+} P<0.1 ;{ }^{*} P<0.05 ;{ }^{* *} P<0.01$

across all treatments, $\mathrm{N}$ concentrations in panicles, leaves, stems, roots, and whole plants were $1.44 \%, 2.33 \%$, $0.90 \%, 1.17 \%$, and $1.37 \%$, respectively at 82 DAT. Then, they varied to $1.22 \%, 1.71 \%, 0.69 \%, 1.25 \%$, and $1.15 \%$, respectively at $99 \mathrm{DAT}$. At the end of the season, N concentrations in all four tissues and whole plants have fallen to $1.21 \%, 0.91 \%, 0.60 \%, 1.00 \%$, and $1.00 \%$, respectively (Fig. 1).

Overall, elevated $\left[\mathrm{CO}_{2}\right]$ notably decreased $(P<0.05)$ plant $\mathrm{N}$ concentrations regardless of cultivars and $\mathrm{N}$ fertilization across the study period except for panicles and roots at $82 \mathrm{DAT}$ (Fig. 1, Table 2). Compared to ambient, $\mathrm{N}$ concentrations in panicles, leaves, stems, roots, and whole plants exposure to increased $\left[\mathrm{CO}_{2}\right]$ significantly declined by $8.40 \%, 15.7 \%, 24.9 \%, 8.20 \%$, and $14.8 \%$, respectively at 99 DAT and by $10.2 \%, 22.4 \%$, $30.7 \%, 18.0 \%$, and $15.4 \%$, respectively at maturity. In addition, $\mathrm{N}$ concentrations in leaves at $82 \mathrm{DAT}$
$(P<0.01)$ and maturity $(P<0.1)$, as well as that in panicles at maturity $(P<0.01)$, were significantly affected by cultivar effects. At maturity, WYJ23 had 7.60\% lower panicle $\mathrm{N}$ concentrations but $16.4 \%$ greater leaf $\mathrm{N}$ concentrations across all $\left[\mathrm{CO}_{2}\right]$ and $\mathrm{N}$ levels.

Averaged across all $\left[\mathrm{CO}_{2}\right]$ levels and cultivars, $\mathrm{N}$ fertilization significantly stimulated $\mathrm{N}$ concentrations in panicles, leaves, stems, roots, and whole plants by $14.5 \%$, $38.6 \%, 83.5 \%, 31.4 \%$, and $54.3 \%$, respectively at $82 \mathrm{DAT}$ and by $32.5 \%, 81.2 \%, 136.8 \%, 24.2 \%$, and $77.3 \%$, respectively at 99 DAT and by 30.0\%, 91.2\%, 105.7\%, 65.6\% and $44.8 \%$, respectively at maturity. In addition, significant interactions of cultivar $\times \mathrm{N}(P<0.01)$ at both 99 DAT and maturity, and that of $\mathrm{CO}_{2} \times$ cultivar $\times \mathrm{N}(P<0.05)$ at maturity were observed on the $\mathrm{N}$ concentrations in panicles. Among all treatments, fertilized IIY084 under ambient had the greatest values at these two stages (Fig. 1, Table 2). 


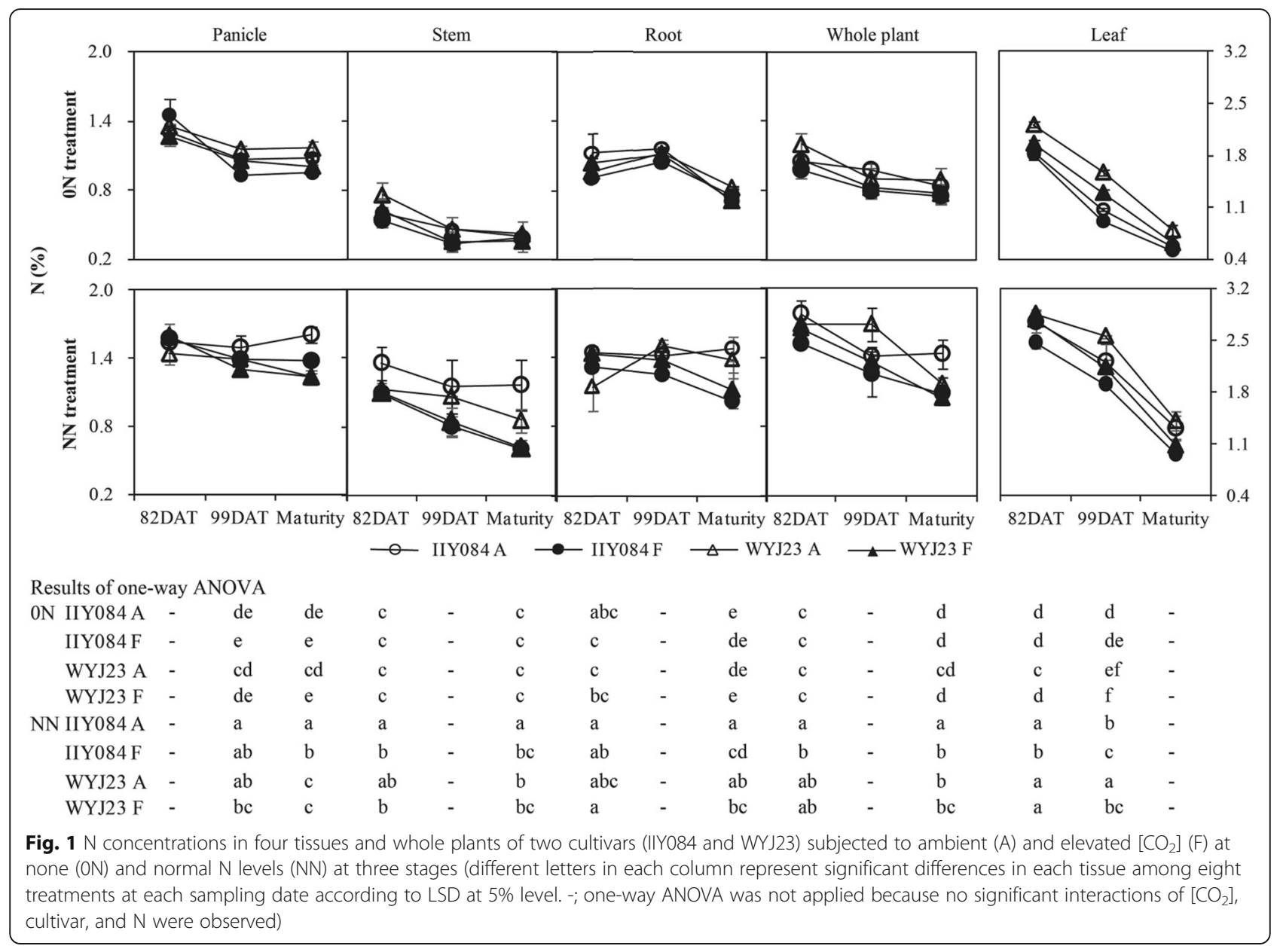

\section{$\mathrm{N}$ amounts in four tissues and whole plants}

Averaged across all cultivars and $\mathrm{N}$ levels, elevated $\left[\mathrm{CO}_{2}\right]$ significantly increased $(P<0.05) \mathrm{N}$ amounts in roots by $28.8 \%$ at 82 DAT but decreased it in leaves $(P<$ $0.05)$ and stems $(P<0.01)$ by $25.0 \%$ and $26.8 \%$, respectively at maturity. As compared to WYJ23, IIY084 had $50.0 \%, 39.3 \%$, and $18.2 \%$ greater panicle $\mathrm{N}$ amounts at 82 DAT $(P<0.01)$, 99 DAT $(P<0.01)$, and maturity $(P$ $<0.05)$, separately across all $\left[\mathrm{CO}_{2}\right]$ and $\mathrm{N}$ levels. Also, $\mathrm{N}$ amounts in roots at maturity were dramatically affected $(P<0.01)$ by cultivar factor with greater values being observed in WYJ23 (Fig. 2).

$\mathrm{N}$ supply significantly increased $(P<0.01) \mathrm{N}$ amounts in panicles, leaves, stems, roots, and whole plants over the study period. Take the maturity for example, they enhanced by $48.8 \%, 278.9 \%, 157.4 \%, 78.2 \%$, and $81.1 \%$, respectively over non-fertilized plants averaged across cultivars and $\left[\mathrm{CO}_{2}\right]$ levels. Cultivar $\times \mathrm{N}$ interactions notably influenced $(P<0.05)$ the $\mathrm{N}$ amounts in panicles, stems, and whole plants at maturity with the greatest values being detected in fertilized IIY084 regardless of $\left[\mathrm{CO}_{2}\right]$ levels (Fig. 2).
$\mathrm{N}$ use efficiency (NUE) for four tissues and whole plants NUE represents the amount of dry matter yield produced per unit absorbed N. In the present investigation, NUE for tissues and whole plants generally enhanced with the crop development (Fig. 3). Averaged across cultivars and $\mathrm{N}$ levels, NUE for all tissues and whole plants notably raised by $9.7 \%, 18.0 \%, 30.4 \%, 8.4 \%$, and $16.5 \%$, respectively at $99 \mathrm{DAT}$ and by $11.2 \%, 23.3 \%, 24.2 \%$, $15.3 \%$, and $15.7 \%$, separately at maturity under FACE condition (Table 2).

In the case of cultivar effects, significant differences $(P$ $<0.01$ ) in NUE for leaves between IIY084 and WYJ23 were detected during the study period. Averaged across all $\left[\mathrm{CO}_{2}\right]$ and $\mathrm{N}$ levels, IIY084 had $10.4 \%, 13.8 \%$, and $16.8 \%$ greater NUE for leaves at $82 \mathrm{DAT}, 99 \mathrm{DAT}$, and maturity, respectively (Fig. 3, Table 2). Here, we can also find significantly negative $\mathrm{N}$ effects $(P<0.01)$ on the NUE across the grain filling. Compared to non-fertilized plants, N supply dramatically declined NUE for panicles, leaves, stems, roots, and even whole plants by $13.0 \%$, $29.3 \%, 47.2 \%, 22.7 \%$, and $35.5 \%$, respectively at 82 DAT; by $24.8 \%, 45.5 \%, 56.6 \%, 18.9 \%$, and $37.8 \%$, respectively at 


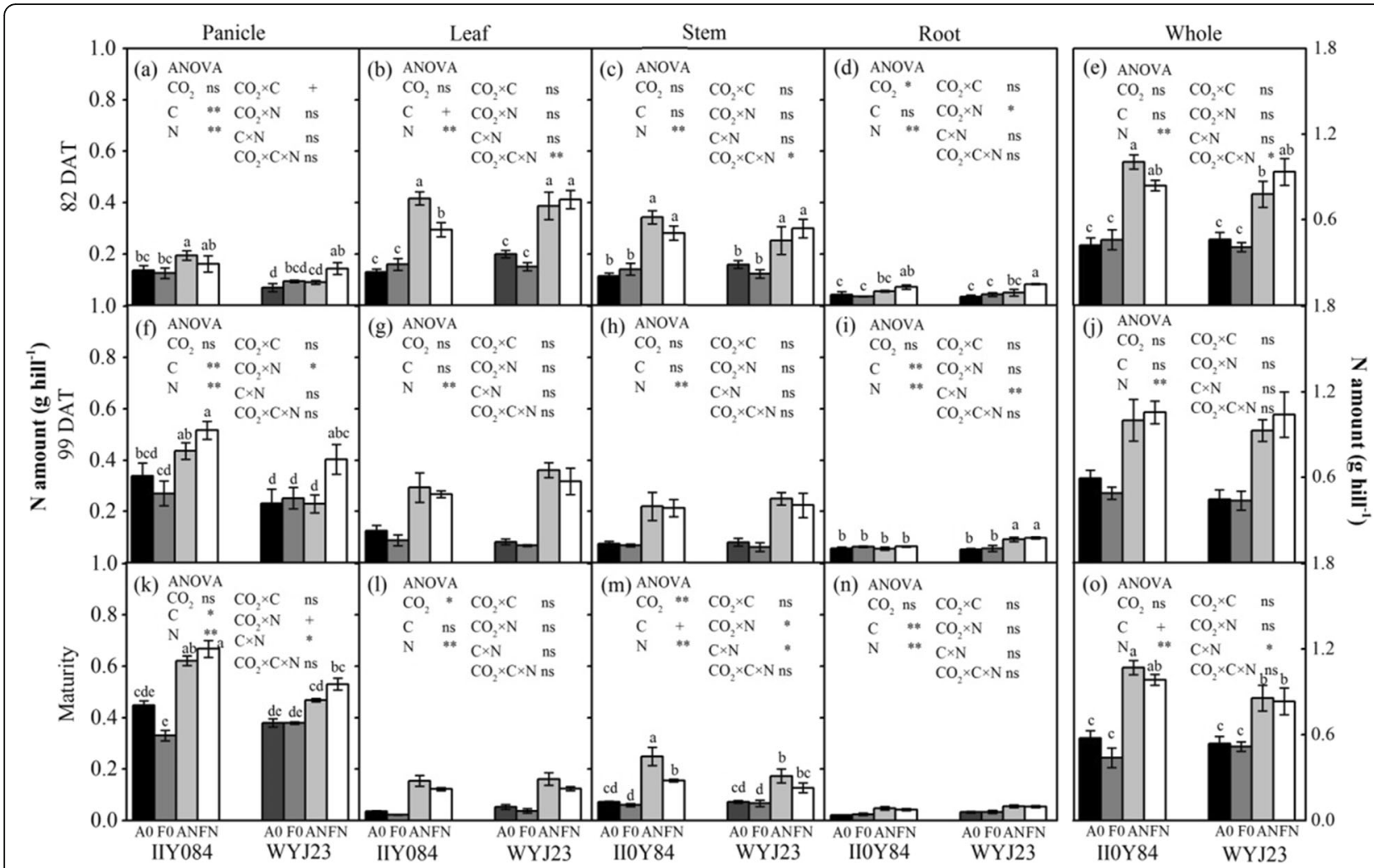

Fig. 2 The $N$ amounts in four tissues and the whole plants of two cultivars (IIY084 and WYJ23) subjected to ambient (A) and elevated [CO $]$ (F) at none (ON) and normal $\mathrm{N}$ levels (NN) at three stages and the results of three-way ANOVA (type III) (different letters represent significant differences in each tissue among eight treatments at each sampling date according to LSD at 5\% level)

99 DAT; and by $22.6 \%, 47.5 \%, 46.8 \%, 37.5 \%$, and $30.0 \%$, separately at maturity regardless of cultivars and $\left[\mathrm{CO}_{2}\right]$ levels.

Moreover, significant cultivar $\times \mathrm{N}$ interactions were found on NUEs for leaves and stems $(P<0.05)$ at 82 DAT, for panicles $(P<0.01)$, and leaves $(P<0.01, P<$ 0.1 ) at 99 DAT and maturity, respectively (Table 2). Regardless of $\left[\mathrm{CO}_{2}\right]$ levels, non-fertilized IIY084 had much greater NUE for panicles than other treatments at latter two stages. A similar trend of NUE for leaves was observed at 82 DAT and maturity (Fig. 3).

\section{$\mathrm{N}$ allocation among the four tissues}

In general, $\mathrm{N}$ partition to panicles sharply increased irrespective of $\left[\mathrm{CO}_{2}\right], \mathrm{N}$ levels, and cultivars during the grain filling (Fig. 4). At maturity, $57.5-77.1 \%$ of the $\mathrm{N}$ was allocated to the panicles. In contrast, those allocations to leaves and stems continually decreased and were $5.2-18.6 \%$ and $12.6-23 \%$, respectively at harvest. During the study, $\mathrm{N}$ distributed to roots was lowest among four tissues, and it generally, especially for WYJ23, enhanced at $99 \mathrm{DAT}$ and then declined at maturity.

The effects of elevated $\left[\mathrm{CO}_{2}\right], \mathrm{N}$ application, and cultivar on the $\mathrm{N}$ distribution differed among the four tissues. Significant $\left[\mathrm{CO}_{2}\right]$ effects were observed on panicles $(P<0.05$, 99 DAT; $P<0.01$, maturity), leaves $(P<$ 0.01, 82 DAT; $P<0.1$, 99 DAT; $P<0.01$, maturity), and stems $(P<0.05$, 99 DAT; $P<0.01$, maturity). At maturity, the relative change ratios of $\mathrm{N}$ allocation to panicles, leaves, stems, and roots exposure to elevated $\left[\mathrm{CO}_{2}\right]$ were $7.0 \%,-18.5 \%,-16.4 \%$, and $9.6 \%$, respectively across two cultivars and $\mathrm{N}$ levels when compared to ambient (Fig. 4).

Averaged across all $\left[\mathrm{CO}_{2}\right]$ and $\mathrm{N}$ levels, WYJ23 had $37.0 \%, 12.1 \%$, and $5.7 \%$ lower panicle $\mathrm{N}$ percentage at 82 DAT $(P<0.01)$, 99 DAT $(P<0.05)$, and maturity $(P<$ $0.05)$, respectively as compared to IIY084. However, significantly greater $(P<0.01) \mathrm{N}$ allocations to leaves at 82 DAT $(22.3 \%)$ and maturity (32.9\%) and to roots at 99 DAT (35.6\%) and maturity (41.2\%) were found in WJY23. Regardless of $\left[\mathrm{CO}_{2}\right]$ and cultivars, $\mathrm{N}$ fertilization significantly decreased the $\mathrm{N}$ fractions in panicles $(P<$ 0.01 ), while increasing those in leaves during study period. Also, positive $\mathrm{N}$ effects $(P<0.05)$ were observed on the stem $\mathrm{N}$ percentages at the latter two stages.

Moreover, there were significant $\mathrm{CO}_{2} \times$ cultivar interactions on the $\mathrm{N}$ fractions in panicles at $82 \mathrm{DAT}(P<$ $0.01)$ and $99 \operatorname{DAT}(P<0.1)$. Also, significant $\mathrm{CO}_{2} \times$ 


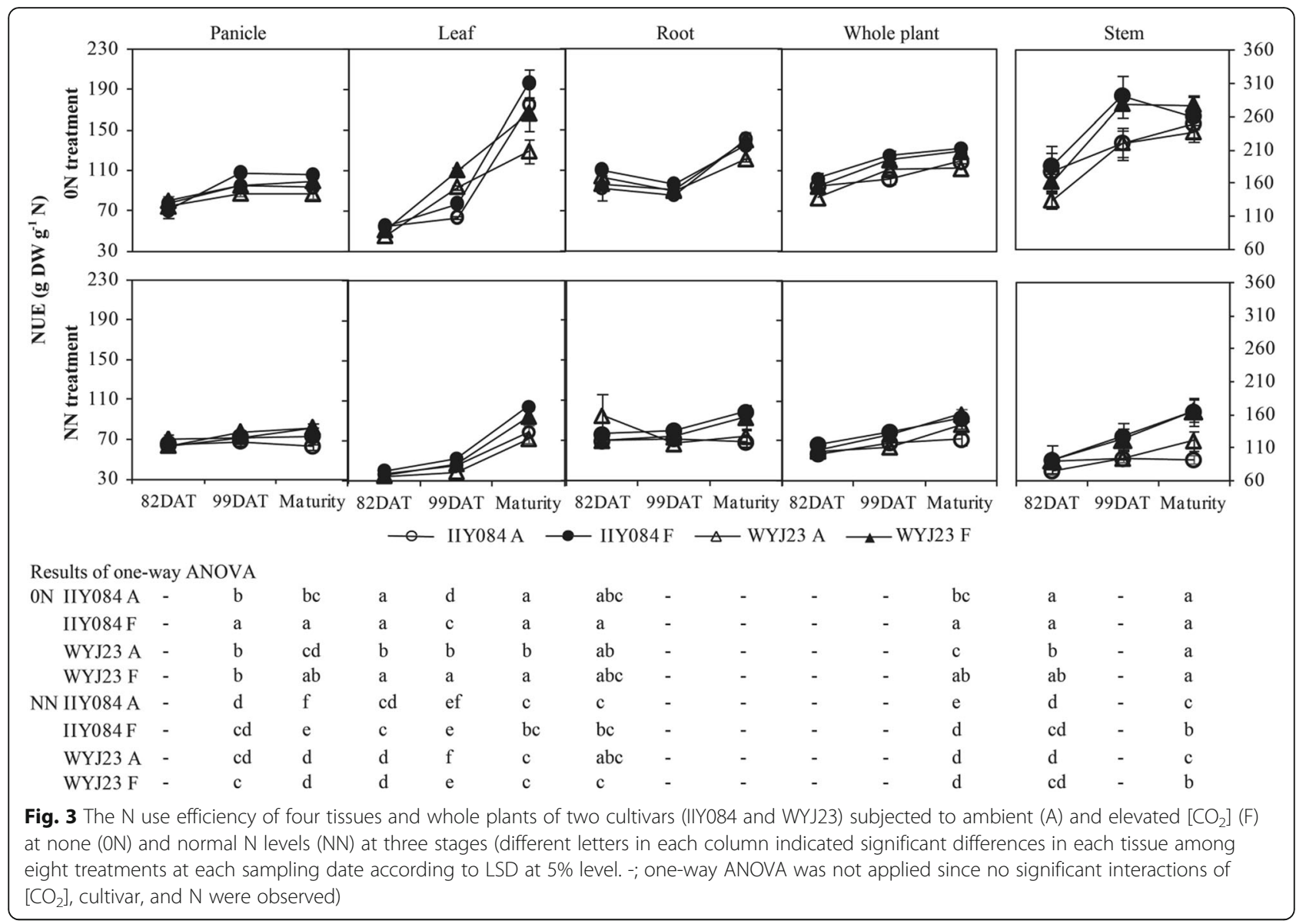

cultivar $\times \mathrm{N}$ interactions were detected on the $\mathrm{N}$ fractions in panicles $(P<0.01)$ and leaves $(P<0.05)$ at 82 DAT. At this sampling stage, we can find that under ambient, non-fertilized IIY084 had the greatest $\mathrm{N}$ fractions in panicles, and fertilized WYJ23 had the greatest values in leaves (Fig. 4).

\section{Discussion}

\section{$\mathrm{N}$ concentration}

In the present investigation, $\mathrm{N}$ concentrations in each tissue across all treatments generally declined with the crop development. The biggest decrease appeared to be in the leaves, where the $\mathrm{N}$ concentrations at the first stage were highest among four tissues, but was almost one quarter at maturity. This, together with the increased leaf senescence observed in this study, indicated a fast $\mathrm{N}$ remobilization from green leaves to grains during the grain filling (Kim et al. 2003), which also can be testified by the result of $\mathrm{N}$ distribution (Fig. 4). Moreover, panicles had the greatest $\mathrm{N}$ concentrations among all tissues to ensure the grain quality at the harvest time.

Except for panicles and roots at 82 DAT, elevated $\left[\mathrm{CO}_{2}\right]$ significantly suppressed $\mathrm{N}$ concentrations in the four tissues as well as the whole plants. The reduction in $\mathrm{N}$ concentrations in rice plants under rising $\left[\mathrm{CO}_{2}\right]$ was widely reported (Myers et al. 2014; Pang et al. 2006; Zhu et al. 2018). Recently, a comprehensive meta-analysis involving 386 published reports and including 4481 observations confirmed that elevated $\left[\mathrm{CO}_{2}\right]$ significantly reduced the plant $\mathrm{N}$ concentration by $9.73 \%(P<0.001)$ (Du et al. 2019). Furthermore, the mechanisms underlying the phenomenon have been well illustrated. There have been various explanations such as the limited soil available $\mathrm{N}$ supply, restricted $\mathrm{N}$ absorption, and transportation by roots, increased plant $\mathrm{N}$ loss, and decreased root $\mathrm{N}$ uptake efficiency, and unbalanced translocation of $\mathrm{C}$ and $\mathrm{N}$ in plants at increasing $\left[\mathrm{CO}_{2}\right]$ (Feng et al. 2015; Guo et al. 2015a; Leakey et al. 2009; Pang et al. 2006). Here, given the unchanged total $\mathrm{N}$ accumulations and $\mathrm{N}$ allocation to roots, and the increasing trend of soil available $\mathrm{N}$ (Wu et al. 2020), it is more likely attributed to the $\mathrm{C}$ gain outstripped the $\mathrm{N}$ uptake of rice plants exposed to rising $\left[\mathrm{CO}_{2}\right]$ (Guo et al. 2015a). In addition, the responses of different tissues to increasing $\left[\mathrm{CO}_{2}\right]$ were of different magnitudes as exhibited by Fig. $1, \mathrm{~N}$ concentrations decreasing more in leaves and stems than in other tissues. This is in accordance with the view 


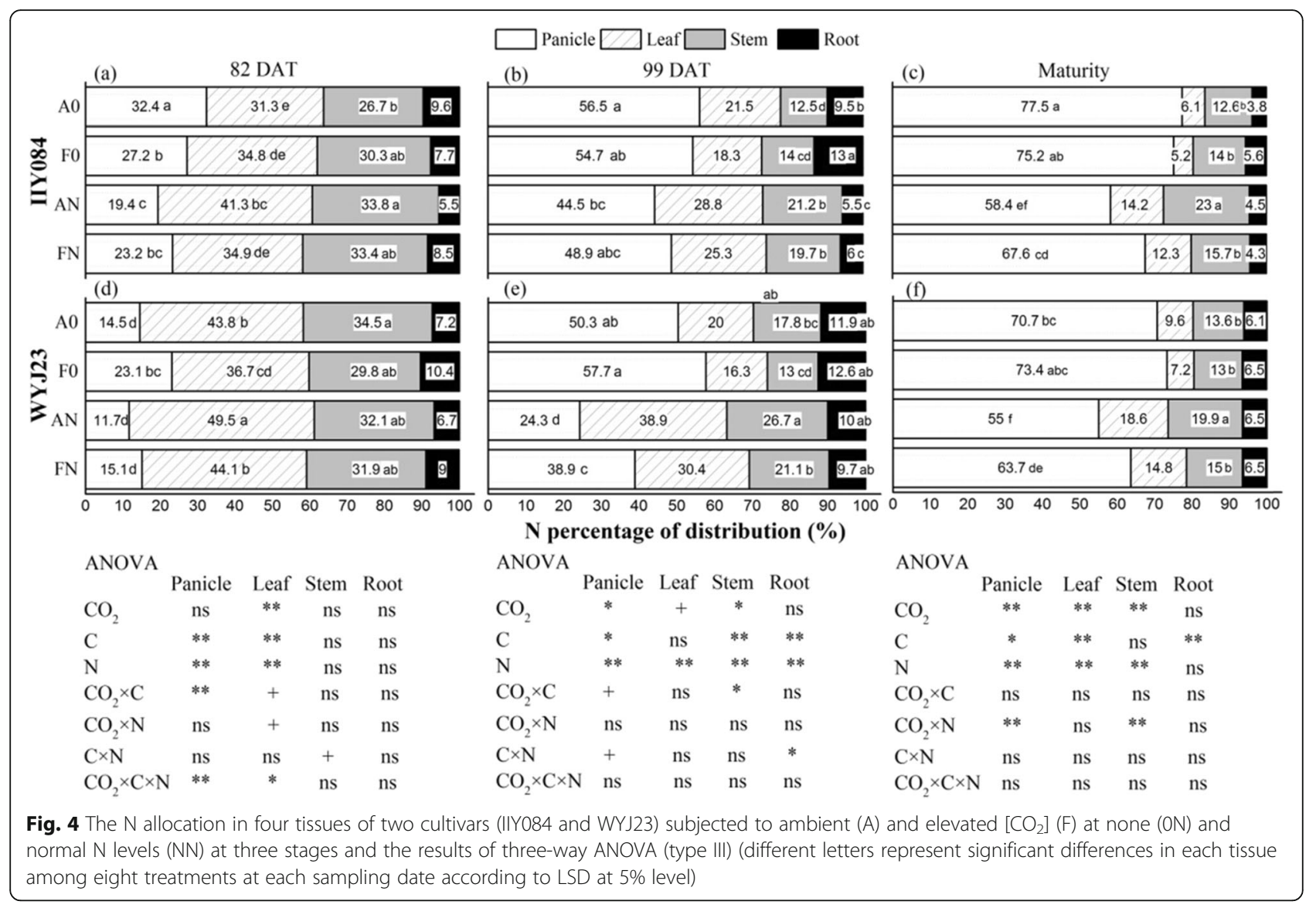

that different plant tissues have different metabolic pathways that get changed at elevated $\left[\mathrm{CO}_{2}\right]$ (Du et al. 2019).

At 82 DAT and 99 DAT, IIY084 had greater panicle biomass but undifferentiated $\mathrm{N}$ concentrations compared to WYJ23 across all $\left[\mathrm{CO}_{2}\right]$ and $\mathrm{N}$ levels. At maturity, however, IIY084 had unchanged panicle biomass and greater $\mathrm{N}$ concentrations. This result might be explained by the accelerated $\mathrm{N}$ accumulation in IIY084 over the study period reflecting a better nutrition quality of grain. As expected, $\mathrm{N}$ supply significantly increased $\mathrm{N}$ concentrations in four tissues and whole plants throughout three stages. Similar results have been found with rice plants (Kim et al. 2003; Yang et al. 2007a). Moreover, we can find that fertilized IIY084 had the greatest $\mathrm{N}$ concentrations in panicles, revealing that the beneficial effect of N supply on grain N quality was larger for IIY084 than for WYJ23.

\section{$\mathrm{N}$ use efficiency}

The NUE has been used as a long-term indicator on availability of $\mathrm{N}$ utilization for $\mathrm{C}$ acquisition in plants. In the current experiment, NUE for stem was greater than other rice tissues across the three stages regardless of all treatments variables, reflecting with the same available
$\mathrm{N}$; greatest biomass would be observed on stems among all tissues. It had been reported that NUE for rice shoots was enhanced by FACE from middle-tillering to grain maturity stages (Yang et al. 2007a). In this study, greater NUE for whole plants was recorded under elevated $\left[\mathrm{CO}_{2}\right]$ during grain filling, which represented that the same amount of $\mathrm{N}$ accumulated in plants at elevated $\left[\mathrm{CO}_{2}\right]$ and ambient, greater dry matter will be produced under FACE. Similarly, the positive responses of NUE to elevated $\left[\mathrm{CO}_{2}\right]$ were reported in other plant species (Wei et al. 2018). These results could be attributed to the increased biomass and/or decreased $\mathrm{N}$ content of plants exposure to elevated $\left[\mathrm{CO}_{2}\right]$ (Kim et al. 2001; Reddy et al. 2010). At the same FACE platform, significantly increased NUE for leaves, stems, panicles, and the total aboveground was found at harvest (Guo et al. 2015b). However, the NUE for each tissue during the grain filling is not well reported, which could reveal the responses of the grain formation to elevated $\left[\mathrm{CO}_{2}\right] \mathrm{com}$ prehensively. In the present investigation, increased NUE for leaves was detected at three stages, while that for panicles, stems, and roots were observed at latter two stages. Early at 40 DAT, NUE for leaf blades of rice was also enhanced by increased $\left[\mathrm{CO}_{2}\right]$ (Seneweera 2011). 
Thus, we can find that as directly exposed to elevated $\left[\mathrm{CO}_{2}\right]$, leaves are more sensitive, and then, its physiology of $\mathrm{N}$ use is easier to be changed than other tissues.

Besides, the NUE could be influenced by cultivar types, cultivation techniques, and nutrients circumstance (Cheng et al. 2011; Gifford et al. 2000; Wei et al. 2018). Here, we can find that IIY084 had greater NUE for leaves than WYJ23 averaged across all $\left[\mathrm{CO}_{2}\right]$ and $\mathrm{N}$ levels, showing it could produce higher leaf dry matter with the similar $\mathrm{N}$ uptake. This may be closely correlated with the different photosynthesis rate of the two cultivars. As revealed by an experiment at the same FACE platform, photosynthetic rate of IIY084 was significantly greater than that of WJY23 at both elevated $\left[\mathrm{CO}_{2}\right]$ and ambient (Chen 2015). It is well known that a large portion of leaf $\mathrm{N}$ is invested in photosynthetic machinery since it is one of the most critical component of chemical compounds which are related to photosynthesis (Kattge et al. 2009; Wang et al. 2018). Thus, as supported by the result of $\mathrm{N}$ concentrations, lower $\mathrm{N}$ was needed in the photosynthesis of IIY084 leaves which consequently led to increased NUE as compared to WYJ23. Likewise, Seneweera (2011) considered that the increased NUE in both rice leaf blades and sheaths resulted from a smaller partitioning of $\mathrm{N}$ to photosynthetic processes. However, the interactive effects of $\left[\mathrm{CO}_{2}\right]$ and cultivar were undetected during the study period except for the root NUE at $82 \mathrm{DAT}$, indicating that in most cases, the differences resulting from the diverse intrinsic properties of the two tested genotypes can not be significantly affected by elevated $\left[\mathrm{CO}_{2}\right]$.

In addition to increasing $\left[\mathrm{CO}_{2}\right]$ and cultivars, NUE for all rice tissues and whole plants was predominantly affected by $\mathrm{N}$ fertilizer with greater values in non-fertilized plants across three stages. Regardless of $\left[\mathrm{CO}_{2}\right]$ levels, Yang et al. (2007a) found the NUE decreased significantly with increasing $\mathrm{N}$ supply, except during early stages of rice development. Using tomato as a testing material, Wei et al. (2018) also observed greater NUE in $1.5 \mathrm{~g} \mathrm{~N}$ pot $^{-1}$ than in $3.0 \mathrm{~g} \mathrm{~N}^{-1}$ pot $^{-1}$ treatments. Distinctly, the greater NUE in lower $\mathrm{N}$ condition resulted from the exacerbated shortage of $\mathrm{N}$ relative to $\mathrm{C}$ in the plants, whereas the decreased NUE in $\mathrm{N}$ fertilized rice plants would be attributed to the more improvement in uptake of $\mathrm{N}$ than $\mathrm{C}$.

\section{$\mathrm{N}$ uptake and allocation}

With the crop development, a rapid increase in $\mathrm{N}$ accumulation in panicles, while a steady decrease in leaves and stems were observed regardless of all treatment variables. In accordance with this, $\mathrm{N}$ partitioning to panicles sharply increased while those to leaves and stems continually declined. These were consistent with the observation that grain $\mathrm{N}$ can be mainly obtained by $\mathrm{N}$ transfer from the vegetative components of the rice during grain filling (Yang et al. 2007a). As reported by Gregersen et al. (2008), for the small-grained cereals such as barley, wheat, and rice, up to $90 \%$ of the $\mathrm{N}$ were mobilized from vegetative parts.

With respect to the FACE effects, $\mathrm{N}$ amount of total plants remained unchanged. Similar results have been reported elsewhere when rice plants were grown under various conditions (Kim et al. 2001, 2003; Seneweera 2011). On the contrary, other experiments demonstrated that the $\mathrm{N}$ uptake was significantly enhanced by elevated $\left[\mathrm{CO}_{2}\right]$ (Wang et al. 2020; Yang et al. 2007a). Besides the differences induced by cultivars and environmental conditions, the levels of $\mathrm{N}$ fertilization would be responsible for this contrast. The $\mathrm{N}$ supply both in this investigation and the studies cited here (Kim et al. 2001, 2003) was 0$22.5 \mathrm{~g} \mathrm{~N} \mathrm{~m}^{-2}$, while at the experiment of Yang et al. (2007a), it was $15-35 \mathrm{~g} \mathrm{~N} \mathrm{~m}^{-2}$. Therefore, it is considered that the appropriate effect of increasing $\left[\mathrm{CO}_{2}\right]$ on $\mathrm{N}$ uptake closely linked to the soil $\mathrm{N}$ availability (Yang et al. 2007a). Although the total $\mathrm{N}$ amount was unaffected, those in leaves and stems declined by $25.0 \%$ and $26.8 \%$ over ambient plants, respectively at maturity. Furthermore, $\mathrm{N}$ allocations to leaves and stems were suppressed while that to panicles was enhanced at elevated $\left[\mathrm{CO}_{2}\right]$. Both Seneweera (2011) and Yang et al. (2007a) observed the significantly decreased $\mathrm{N}$ fractions in leaves at elevated $\left[\mathrm{CO}_{2}\right]$ and considered that there was an internal mechanism controlling $\mathrm{N}$ partitioning at the whole plant level. In the current experiment, it is possible that as the storage pools, $\mathrm{N}$ would be reallocated away from leaves and stems to the developing grain when the requirement arose, which was triggered by the rising $\left[\mathrm{CO}_{2}\right]$ (Kim et al. 2003). For example, as exposed to elevated $\left[\mathrm{CO}_{2}\right]$, more $\mathrm{C}$ can be fixed by the crops including panicles, and thus, more $\mathrm{N}$ was needed to be transported from vegetative parts to panicles in order to keep the balance between $\mathrm{C}$ and $\mathrm{N}$ as much as possible ( $\mathrm{Du}$ et al. 2019; Guo et al. 2015b).

As mentioned before, $\mathrm{N}$ is important in photosynthesis (Kattge et al. 2009; Wang et al. 2018). In consistent with the findings of Seneweera (2011), accompanied by the greater photosynthetic NUE of IIY084, a large amount of $\mathrm{N}$ was allocated away from the photosynthetic machinery such as to the development of panicles as compared with WYJ23. Generally, roots are the first plant organ that receives nutrients such as $\mathrm{N}$ from the soil, traits like root biomass, length and rooting depth can significantly affect $\mathrm{N}$ uptake rates and NUE in crops (Kim et al. 2001). At 82 DAT, no significant cultivar effects on root biomass and $\mathrm{N}$ accumulation as well as $\mathrm{N}$ allocation were found. Through the rest of the growing stages, however, predominantly lower values were observed in IIY084. In spite of that, there was no 
significant difference between IIY084 and WYJ23 with regard to NUE for roots, and an increasing tendency of $\mathrm{N}$ amount in whole IIY084 plants (maturity, $P<0.1$ ) was observed across the filling duration, which indicated IIY084 roots had greater ability to absorb $\mathrm{N}$ from soils as compared with WYJ23. Besides, we can find that with the rice development, IIY084 was more able to transfer $\mathrm{N}$ from roots to aboveground biomass, especially the panicles, leading to the greater panicle biomass regardless of $\left[\mathrm{CO}_{2}\right]$ and $\mathrm{N}$ levels.

Across the $\left[\mathrm{CO}_{2}\right]$ levels and cultivars, $\mathrm{N}$ accumulations in four tissues as well as the whole plants were dramatically enhanced by $\mathrm{N}$ supply, with a large proportion of $\mathrm{N}$ being partitioned to the leaves and stems at the expense of the panicles during study period. This agrees with other published findings (Yang et al. 2007a). Cheng et al. (2011) reported that the excessive $\mathrm{N}$ application decreased rice $\mathrm{N}$ harvest index, the ratio of $\mathrm{N}$ amount in grain to cumulative $\mathrm{N}$ absorption in whole plants, because excessively absorbed $\mathrm{N}$ was mainly deposited in leaves and straws but not allocated in grains. Those results advised proper application of $\mathrm{N}$ in rice production because excessive $\mathrm{N}$ would lead to wasting, decreasing $\mathrm{N}$ efficiency, and production benefit (Seneweera 2011; Yang et al. 2007b). As indicated by the significant cultivar $\times \mathrm{N}$ interactions at maturity, IIY084 in combination with $\mathrm{N}$ fertilizer had the highest $\mathrm{N}$ accumulations in panicles, stems, and whole plants regardless of $\left[\mathrm{CO}_{2}\right]$ levels. It is suggested that in addition to the reasonable $\mathrm{N}$ application, improvement of rice $\mathrm{N}$ efficiency is also closely related with the cultivar and the interaction of cultivar and $\mathrm{N}$ application.

\section{Conclusions}

Overall, the results here indicated that both elevated $\left[\mathrm{CO}_{2}\right]$ and $\mathrm{N}$ application would affect the $\mathrm{N}$ uptake and utilization of two tested rice genotypes to different extents. In most cases, IIY084 had greater panicle biomass and $\mathrm{N}$ concentrations since more $\mathrm{N}$ was transferred from roots to aboveground, especially the panicles. Furthermore, greater beneficial effects of $\mathrm{N}$ fertilization on the $\mathrm{N}$ uptake and utilization were observed on IIY084 regardless of $\left[\mathrm{CO}_{2}\right]$ levels. Accordingly, IIY084 shows a considerable prospect in terms of its grain yield and quality with additional $\left[\mathrm{CO}_{2}\right]$. Nutritional deficits induced by rising $\left[\mathrm{CO}_{2}\right]$ are likely to occur for a large segment of the global population who are rice-dependent (Myers et al. 2014), and thus, it is necessary to select superior rice cultivar with greater nutrition utilization such as $\mathrm{N}$, either through traditional breeding or genetic modification as well as the optimal fertilizing strategy under future $\mathrm{CO}_{2}$-enriched environment. Additionally, other aspects of climate change need to be considered, especially temperature. An elevation in atmospheric $\mathrm{CO}_{2}$ could result in rising temperature, and thus, the integrated effects of $\mathrm{CO}_{2}$ and temperature on the nutrition uptake and utilization of different rice genotypes are necessary to be investigated in the future.

\section{Supplementary information}

Supplementary information accompanies this paper at https://doi.org/10. 1186/s13717-020-00238-5.

Additional file 1: Supplementary Table S1. The schedule of fertilization in this experiment $\left(\mathrm{g} \mathrm{m}^{-2}\right)$.

\section{Abbreviations}

$\mathrm{CO}_{2}$ : Carbon dioxide; FACE: Free-air $\mathrm{CO}_{2}$ enrichment; N: Nitrogen; IIY084: Indica CV. Liangyou 084; WYJ23: Japonica CV. Wuyunjing 23; P: Phosphorus; K: Potassium; DAT: Days after transplanting; NUE: N use efficiency; ANOVA: Analysis of variance; ns: Not significant; C: Carbon

\section{Acknowledgements}

This work was financially supported by the National Basic Research Program of China (2014CB954500) and National Natural Science Foundation of China (31261140364, 31370457).

\section{Authors' contributions}

QJ and JZ conceived the study and designed the experiments. QJ, JZ, and XX performed the experiments. QJ and GL analyzed the data with suggestions by JZ. QJ and JZ wrote the manuscript. All authors have read and approved the final manuscript.

\section{Funding}

National Basic Research Program of China (2014CB954500) and National Natural Science Foundation of China (31261140364, 31370457). The funders had no role in the study design, data collection and analysis, decision to publish, or preparation of the manuscript.

Availability of data and materials Not applicable

Ethics approval and consent to participate Not applicable

Consent for publication

Not applicable

\section{Competing interests}

The authors declare that they have no competing interests.

\section{Author details}

${ }^{1}$ State Key Laboratory of Soil and Sustainable Agriculture, Institute of Soil Science, Chinese Academy of Sciences, No. 71 East Beijing Road, Nanjing 210008, China. ${ }^{2}$ University of Chinese Academy of Sciences, Beijing 100049, China.

Received: 23 February 2020 Accepted: 26 May 2020

Published online: 29 June 2020

\section{References}

Baker JT (2004) Yield responses of southern US rice cultivars to $\mathrm{CO}_{2}$ and temperature. Agric For Meteorol 122:129-137

Chen C (2015) Spikelet formation and seed vigor of contrasting rice cultivars in response to elevated carbon dioxide. University of Chinese Academy of Sciences, Beijing (in Chinese)

Chen C, Jiang Q, Zisk LH, Zhu JG, Liu G, Zhang JS, Kang N, Seneweera S, Zhu CW (2015) Seed vigor of contrasting rice cultivars in response to elevated carbon dioxide. Field Crop Res 178:63-68

Cheng JF, Jiang HY, Liu YB, Dai TB, Cao WX (2011) Methods on identification and screening of rice genotypes with high nitrogen efficiency. Rice Sci 18:127135 
Coviella CE, Trumble JT (1999) Effects of elevated atmospheric carbon dioxide on insect-plant interactions. Conserv Biol 13:700-712

Du CJ, Wang XD, Zhang MY, Jing J, Gao YH (2019) Effects of elevated $\mathrm{CO}_{2}$ on plant C-N-P stoichiometry in terrestrial ecosystems: a meta-analysis. Sci Total Environ 650:697-708

Feng ZZ, Rütting T, Pleijel H, Wallin G, Reich PB, Kammann Cl, Newton PCD, Kobayashi K, Luo YJ, Uddling J (2015) Constraints to nitrogen acquisition of terrestrial plants under elevated $\mathrm{CO}_{2}$. Glob Chang Biol 21:3152-3168

Gifford RM, Barrett DJ, Lutze $J$ (2000) The effects of elevated $\left[\mathrm{CO}_{2}\right]$ on the C:N and C:P mass ratios of plant tissues. Plant Soil 224:1-14

Gregersen PL, Holm PB, Krupinska K (2008) Leaf senescence and nutrient remobilisation in barley and wheat. Plant Biol 10:37-49

Guo J, Zhang MQ, Wang XW, Zhang WJ (2015a) A possible mechanism of mineral responses to elevated atmospheric $\mathrm{CO}_{2}$ in rice grains. J Integr Agric 14:50-57

Guo J, Zhang MQ, Wang XW, Zhang WJ (2015b) Elevated $\mathrm{CO}_{2}$ facilitates $C$ and $\mathrm{N}$ accumulation in a rice paddy ecosystem. J Environ Sci-China 29:27-33

Kattge J, Knorr W, Raddatz T, Wirth C (2009) Quantifying photosynthetic capacity and its relationship to leaf nitrogen content for global-scale terrestrial biosphere models. Glob Chang Biol 15:976-991

Kim HY, Lieffering M, Kobayashi K, Okada M, Miura S (2003) Seasonal changes in the effects of elevated $\mathrm{CO}_{2}$ on rice at three levels of nitrogen supply: a free air $\mathrm{CO}_{2}$ enrichment (FACE) experiment. Glob Chang Biol 9:826-837

Kim HY, Lieffering M, Miura S, Kobayashi K, Okada M (2001) Growth and nitrogen uptake of $\mathrm{CO}_{2}$-enriched rice under field conditions. New Phytol 150:223-229

Kimball BA (2016) Crop responses to elevated $\mathrm{CO}_{2}$ and interactions with $\mathrm{H}_{2} \mathrm{O}, \mathrm{N}$, and temperature. Curr Opin Plant Biol 31:36-43

Leakey AD, Ainsworth EA, Bernacchi CJ, Rogers A, Long SP, Ort DR (2009) Elevated $\mathrm{CO}_{2}$ effects on plant carbon, nitrogen, and water relations: six important lessons from FACE. J Exp Bot 60:2859-2876

Li CH, Zhu JG, Sha LN, Zhang JS, Zeng Q, Liu G (2017) Rice (Oryza sativa L.) growth and nitrogen distribution under elevated $\mathrm{CO}_{2}$ concentration and air temperature. Ecol Res 32:405-411

Liang XQ, Li H, Wang SX, Ye YS, Ji YJ, Tian GM, van Kessel C, Linquistd BA (2013) Nitrogen management to reduce yield-scaled global warming potential in rice. Field Crop Res 146:66-74

Liu G, Han Y, Zhu JG, Okada M, Nakamura H, Yoshimoto M (2002) Rice-wheat rotational FACE platform I. System structure and control. Chin J Appl Ecol 13: 1253-1258 (in Chinese)

Lv CH, Huang Y, Sun WJ, Yu LF, Zhu JG (2020) Response of rice yield and yield components to elevated $\left[\mathrm{CO}_{2}\right]$ : a synthesis of updated data from FACE experiments. Eur J Agron 112:125961

McLeod AR, Long SP (1999) Free air carbon dioxide enrichment (FACE) in global change research: a review. Adv Ecol Res 28:1-56

Metz B, Davidson OR, Bosch PR, Dave R, Meyer LA (2007) IPCC: Fourth Assessment Report: Climate Change 2007 (AR4), Cambridge, UK: Cambridge University Press, p 1075

Myers SS, Zanobetti A, Kloog I, Huybers P, Leakey ADB, Bloom A, Carlisle E, Dietterich LH, Fitzgerald G, Hasegawa T, Holbrook NM, Nelson RL, Ottman MJ, Raboy V, Sakai H, Sartor KA, Schwartz J, Seneweera S, Tausz M, Usui Y (2014) Increasing $\mathrm{CO}_{2}$ threatens human nutrition. Nature 510:139-142

Pang J, Zhu JG, Xie ZB, Liu G, Zhang YL, Chen GP, Zeng Q, Cheng L (2006) A new explanation of the $\mathrm{N}$ concentration decrease in tissues of rice (Oryza sativa L.) exposed to elevated atmospheric $\mathrm{pCO}_{2}$. Environ Exp Bot 57:98-105

Reddy AR, Rasineni GK, Raghavendra AS (2010) The impact of global elevated $\mathrm{CO}_{2}$ concentration on photosynthesis and plant productivity. Curr Sci 99:46-57

Roberts TL, Ross WJ, Norman RJ, Slaton NA (2011) Predicting nitrogen fertilizer needs for rice in Arkansas using alkaline hydrolysable nitrogen. Soil Sci Soc Am J 75:1161-1171

Seneweera S (2011) Effects of elevated $\mathrm{CO}_{2}$ on plant growth and nutrient partitioning of rice (Oryza sativa L.) at rapid tillering and physiological maturity. J Plant Interact 6:35-42

Shi GY, Yang LX, Wang YX, Kobayashi K, Zhu JG, Tang HY, Pan ST, Chen T, Liu G, Wang YL (2009) Impact of elevated ozone concentration on yield of four Chinese rice cultivars under fully open-air field conditions. Agric Ecosyst Environ 131:178-184

Tausz M, Tausz-Posch S, Norton RM, Fitzgerald GJ, Nicolas ME, Seneweera S (2013) Understanding crop physiology to select breeding targets and improve crop management under increasing atmospheric $\mathrm{CO}_{2}$ concentrations. Environ Exp Bot 88:71-80
Terao T, Miura S, Yanagihara T, Hirose T (2005) Influence of free-air $\mathrm{CO}_{2}$ enrichment (FACE) on the eating quality of rice. J Sci Food Agric 85:1861-1868

Viswanath T, Pal D, Purakayastha TJ (2010) Elevated $\mathrm{CO}_{2}$ reduces rate of decomposition of rice and wheat residues in soil. Agric Ecosyst Environ 139: 557-564

Wang B, Guo C, Wan YF, Li JL, Ju XT, Cai WW, You SC, Qin XB, Wilkes A, Li YE (2020) Air warming and $\mathrm{CO}_{2}$ enrichment increase $\mathrm{N}$ use efficiency and decrease $\mathrm{N}$ surplus in a Chinese double rice cropping system. Sci Total Environ 706:136063

Wang J, Wen XF, Zhang XY, Li SG, Zhang DY (2018) Co-regulation of photosynthetic capacity by nitrogen, phosphorus and magnesium in a subtropical Karst forest in China. Sci Rep 8:7406

Wei D, Cui KH, Pan JF, Ye GY, Xiang J, Nie LX, Huang JL (2011) Genetic dissection of grain nitrogen use efficiency and grain yield and their relationship in rice. Field Crop Res 124:340-346

Wei ZH, Du TS, Li XN, Fang L, Liu FL (2018) Interactive effects of $\mathrm{CO}_{2}$ concentration elevation and nitrogen fertilization on water and nitrogen use efficiency of tomato grown under reduced irrigation regimes. Agr Water Manage 202:174-182

Wu QC, Zhang CZ, Liang XQ, Zhu CW, Wang TY, Zhang JB (2020) Elevated $\mathrm{CO}_{2}$ improved soil nitrogen mineralization capacity of rice paddy. Sci Total Environ 710:136438

Yang LX, Huang JY, Yang HJ, Dong GC, Liu HJ, Liu G, Zhu JG, Wang YL (2007a) Seasonal changes in the effects of free-air $\mathrm{CO}_{2}$ enrichment (FACE) on nitrogen $(\mathrm{N})$ uptake and utilization of rice at three levels of $\mathrm{N}$ fertilization. Field Crop Res 100:189-199

Yang LX, Liu HJ, Wang YX, Zhu JG, Huang JY, Liu G, Dong GC, Wang YL (2009) Yield formation of $\mathrm{CO}_{2}$-enriched inter-subspecific hybrid rice cultivar Liangyoupeijiu under fully open-air field condition in a warm sub-tropical climate. Agric Ecosyst Environ 129:193-200

Yang LX, Wang YL, Dong GC, Gu H, Huang JY, Zhu JG, Yang HJ, Liu G, Han Y (2007b) The impact of free-air $\mathrm{CO}_{2}$ enrichment (FACE) and nitrogen supply on grain quality of rice. Field Crop Res 102:128-140

Zhang GY, Sakai H, Usui Y, Tokida T, Nakamur H, Zhu CW, Fukuoka M, Kobayashi K, Hasegawa T (2015) Grain growth of different rice cultivars under elevated $\mathrm{CO}_{2}$ concentrations affects yield and quality. Field Crop Res 179:72-80

Zhu CW, Kobayashi K, Loladze I, Zhu JG, Jiang Q, Xu X, Liu G, Seneweera S, Ebi $\mathrm{KL}$, Drewnowski A, Fukagawa NK, Ziska LH (2018) Carbon dioxide $\left(\mathrm{CO}_{2}\right)$ levels this century will alter the protein, micronutrients, and vitamin content of rice grains with potential health consequences for the poorest rice-dependent countries. Sci Adv 4:eaaq1012

Zhu CW, Xu X, Wang D, Zhu JG, Liu G, Seneweera S (2016) Elevated atmospheric $\left[\mathrm{CO}_{2}\right]$ stimulates sugar accumulation and cellulose degradation rates of rice straw. GCB Bioenergy 8:579-587

Ziska LH, Manalo PA, Ordonez RA (1996a) Intraspecific variation in the response of rice (Oryza sativa L.) to increased $\mathrm{CO}_{2}$ : evaluation of 17 cultivars. J Exp Bot 47:1353-1359

Ziska LH, Weerakoon W, Namuco OS, Pamplona R (1996b) The influence of nitrogen on the elevated $\mathrm{CO}_{2}$ response on field-grown rice. Aust J Plant Physiol 23:45-52

\section{Publisher's Note}

Springer Nature remains neutral with regard to jurisdictional claims in published maps and institutional affiliations. 